\title{
Marine Algae: Natural Source for Antiviral Compounds to Combat COVID-19
}

\section{Amar S Musale*, G Raja Krishna Kumar, Venkatesh Prasad, Ajit Sapre and Santanu Dasgupta}

Reliance Research and Development Centre, Reliance Corporate Park, Navi

Mumbai, India

*Corresponding Author: Amar S Musale, Reliance Research and Development

Centre, Reliance Corporate Park, Navi Mumbai, India.
Received: March 17, 2021

Published: April 15, 2021

(C) All rights are reserved by Amar S Musale., et al.

\section{Graphical Abstract}

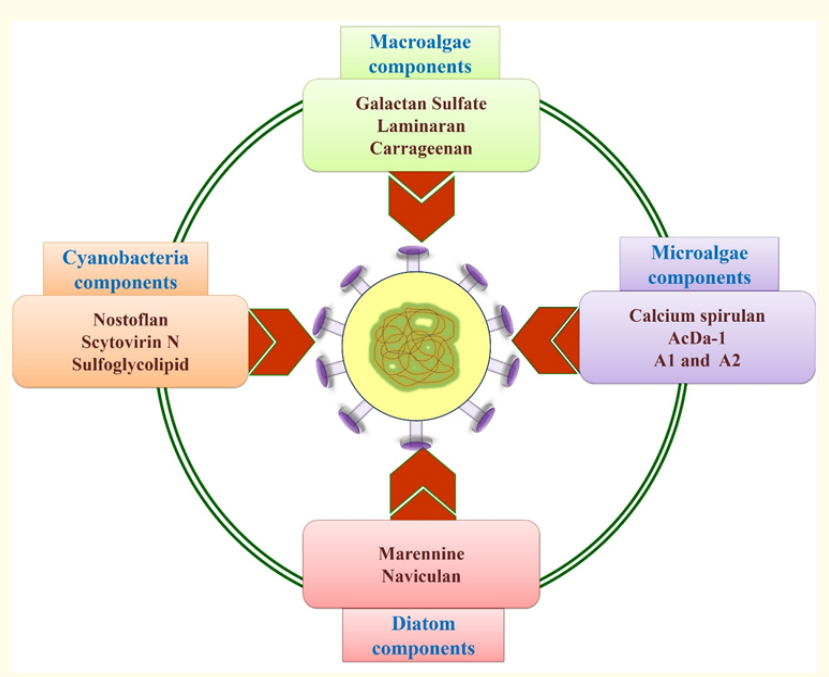

\section{Abstract}

The global outbreak of a new coronavirus resulted in a health crisis and declared as a pandemic by World Health Organization, (WHO). To manage the extensive morbidity and mortality rates in humans, is a healthcare solution that provides adaptive immunity during different exposure levels. Healthcare specialists around the world are working to develop an effective vaccine. In cases where humans are resistant to therapy and prophylaxis, harnessing natural sources for chemically diverse antiviral lead entities, has a potential for therapeutic development against deadly diseases. Marine microorganisms are known producers of such unique biomolecules with pharmacological properties with the potential for the treatment and control of various human diseases. In this direction, microalgae, Cyanobacteria and macroalgae are an untapped resources for potential antiviral molecules. Several cyclic or linear peptides and depsipeptides isolated from these sources have demonstrated antimicrobial activity, in in vitro and in vivo studies which has their potential as therapeutic drugs. This review summarizes the current state of understanding of marine-derived biomolecules and their potential as therapeutic drugs. It is assumed that this comprehensive information will encourage scientists and healthcare professionals to research further to understand the potential of these biomolecules for future development towards improving life.

Keywords: COVID-19; Antiviral; Marine Algae; Cyanobacteria; Biomolecules; Vaccine; Therapeutic Drugs 


\section{Highlights}

- Overview of global outbreak COVID-19 pandemic.

- Review of marine algal-derived biomolecules and their potential as antivirals and therapeutic drugs.

- Several cyclic or linear peptides and depsipeptides isolated from Cyanobacteria are protease inhibitors which are very effective against viral diseases.

- Reviewed comprehensive information will encourage scientists and healthcare professionals to research further to understand the potential of these biomolecules for addressing present and future corona virus and related issues.

- Implementation of synthetic biology and digital platforms could be very rapid and accurate ways for the production of antiviral drugs to fight against pandemics.

\section{Introduction}

Many diseases are infectious and severely affect the health of humans, animals and plants. For example, viral diseases such as Diarrhoea (Rotaviruses), Respiratory (Hantavirus), Influenza-A/ H5N1, SARS coronavirus 2003, AIDS (Retrovirus), etc. are few of them. In humans, infectious diseases are responsible for 15 million out of 57 million annual deaths in a global population of 6.2 billion people [1]. Each year, about 2 million people die from acquired immune deficiency syndrome (AIDS), 1.7 million people die from tuberculosis (caused by a mycobacterium, Mycobacterium tuberculosis), and more than 1.6 million people die from diarrheal disease caused by infectious pathogens [2].

The SARS- CoV-2 (COVID-19) has spread across the globe and declared as a pandemic by World Health Organization (WHO). The whole world is struggling to overcome this health issue. Due to mandatory isolation or quarantines, millions of lives have been affected financially, socially and emotionally all around the world. The current COVID-19 outbreak have brought far-reaching consequences to the global economy and could have much serious if the spread is not controlled in time $[3,4]$. Scientists and medical professionals all over the world are working aggressively to control this pandemic.

In an effort to fight against different infectious diseases, scientific advances and efforts have made few major progress. For example, during 1980, the most significant achievement was to overcome the smallpox by vaccination. Again, Polio, Tetanus, Flu Influenza, Hepatitis-A, Hepatitis-B, Rubella, Measles, Chickenpox, etc., have been significantly controlled globally with the help of vaccines. Some diseases like cancer, HIV virus are still remaining throughout the globe. HIV virus alone has killed more than 25 million people in last 25 years. All the scientific efforts are ongoing globally to overcome these diseases.

For many centuries, different natural plant-based medicines are used against various diseases. These medicines have produced by diverse medicinal plants including algae which is one of the best natural source. Algae are the significant component of water bodies such as ocean, rivers, estuaries etc. Both marine and fresh water algae, Cyanobacteria, diatoms have certain compounds (Table 1-3) that can be effective or act as inhibitory agents against many infectious diseases or viruses. To overcome the present coronavirus pandemic, numerous research efforts are on-going globally and the studies have shown that protease inhibitors, which make up the major part of plant derivatives can be very effective in controlling virus-induced infection. Recent studies on eight secondary metabolites from conventional medicinal higher plants on COVID-19 virus protease were performed by using molecular docking analysis. The outcome of the study indicates that, the compounds investigated can interact with major amino acids in the enzyme flap to inhibit the new coronavirus protease enzyme. Among these secondary metabolites, Curcumin, the secondary metabolite of turmeric has the strongest interaction with the COVID-19 protease enzyme [5].

Cyanobacteria has protease inhibitors which are very effective against viruses. Several cyclic or linear peptides and depsipeptides isolated from Cyanobacteria are protease inhibitors, used for the treatment of diseases such as strokes, coronary artery occlusions and pulmonary emphysema [6,7]. Many published literature and their results highlight the significance of algae as antiviral, antibacterial and antimicrobial activities [8]. The present review will highlight some of the antiviral activities of algae which can possibly help in controlling the current pandemic COVID-19. This review could help to the ongoing research efforts on COVID-19, public health and public policy practices across the world in terms of the usages of natural compounds to overcome the viral diseases like recent COVID-19.

\section{Marine algae of interest}

Marine algae are available in ample quantity ranging from diatoms, which are aquatic, microscopic, unicellular organisms, to seaweeds extending over 30 meter. Algae are of economic importance as food, fertilizer, agar-agar, or sources of iodine. Both micro and macroalgae are used for diverse applications such as for human consumption as food and medicines. These algae provide promising source of fatty acids, steroids, carotenoids, polysaccharides, lectins, amino acids, polyketides, agar, alginic acid, carrageenan etc. 
[9]. Seaweeds, due to its various biological properties have been recognized as rich and valuable natural resources of bioactive compounds [10].

Bioactive compounds are a secondary metabolite which at low concentrations applies either beneficial or harmful effects on living organisms. Thus, these bioactive compounds obtained from algae are of interest for potential industrial or medical applications [11]. The natural products which have been discovered from both terrestrial and marine living organisms are more than 1 million. Out of which, $20-25 \%$ have shown antimicrobial, antifungal, anti-protozoan, anti-nematode, anticancer, antiviral or anti-inflammatory properties [12].

\section{Macroalgae}

Macroalgae or seaweeds may be classified into three categories such as Chlorophyceae (Green algae), Pheophyceae (brown algae), and Rhodophyceae (red algae) according to their pigmentation [13]. Seaweeds are being used since many centuries for different purposes such as food, medicines, therapeutics and herbalism, etc. [14].

Sulphated polysaccharides and other bioactive compounds obtained from macroalgae have long been recognized for medical applications. The global utilization of macroalgae is a multi billion dollar industry in terms of its farming, various products and compounds [15]. The interest in same remains high and prior to the 1950 's, the products are also increasingly being used in medical and biochemical research however, which was restricted to the traditional and folk medicines [16]. During the 1980s and 90s, the compounds with biological activities or pharmacological properties were discovered in marine bacteria, invertebrates and algae [10]. During 1977-1987 algae have been the source of about 35\% of the newly discovered chemicals [17], followed by sponges and cnidarians (22\%). However, since 1995, new products from seaweeds started decreasing and attention has now shifted to marine micro-organisms [18]. However, marine algae especially macroalgae contains polysaccharides which has bioactive compounds and highly potential for pharmaceutical or therapeutic industries. Over the last three decades, macroalgae used for the discovery of metabolites and bioactivities has been increased significantly. Many modern research techniques are available to extract the chemicals or natural bioactive compounds of interest from macroalgae [19].

\section{Microalgae}

Microalgae is a diverse group of photosynthetic microorganisms that converts $\mathrm{CO}_{2}$ into valuable compounds such as, biofuels, foods, feed and pharmaceuticals etc. [20]. For many centuries, mi- croalgae have been used as food in ancient civilizations in Asia, Africa and South America. However, in the middle of the last century microalgae biotechnology began to develop and started extensive screening of novel compounds which may leads to the therapeutically useful agents [21].

Microalgae offer an excellent opportunity for the isolation of natural compounds of significant commercial interests in diversified industries such as pharmaceuticals, cosmetics etc. This encouraging fact makes microalgae as potential raw material with a great deal of added value [22]. Many researchers have already shown that, algae may produce antiviral compounds [23,24].

\section{Other selective algae \\ Cyanobacteria}

Cyanobacteria are prokaryotic photosynthetic, oldest microorganism present on the earth [25], which are diverse, highly specialized and well adapted group to various ecological habitats. Cyanobacteria are potentially very rich source of diverse chemical compounds with various industrial applications $[26,27]$. Cyanobacteria are one of the best model organisms for various studies and thus, it is well studied group from a biotechnology point of view. Many scale-up technologies such as open pond, photobioreactors (PBR's) have been developed by algae researchers worldwide [28], due to its high value of future novel therapeutic or pharmaceutical compounds exploration point of view.

Cyanobacteria have been considered a rich source of secondary metabolites with potential diverse biotechnological applications in the pharmacological field. Thus, production of bioactive compounds with commercial and medical applications has increased interest in studying these organisms [27]. Cyanobacteria has rich source of novel compounds with broad spectrum activities such as antiviral, anti-inflammatory, protease inhibition, antimicrobial, immune stimulating agents, antitumor, anticancer, anti-HIV (human immunodeficiency virus), anticoagulant, antifungal, antimalarial, antiprotozoal, and antituberculotic which have been yet unexplored except very few of them [29,30].

\section{Diatom}

Diatoms are diverse and well nanostructured cell wall organisms which has potential bio-geo chemical properties. The photoautotrophic diatoms play significant role in ocean biogeochemical regulation by carbon fixation, which produces oxygen by carbon sequestration through uptake of carbon dioxide and sunlight in the environment. The biggest advantage for pharmaceutical industries from diatoms which holds high contents of oil, saturated 
and unsaturated fatty acids, steroids, lipids and other primary and secondary metabolites. Bioactive metabolites of diatoms can be act as anticancer, antioxidant and antibacterial drugs [31]. Marine microorganisms or diatoms are known for its proteins, polysaccharides and bioactive compounds which acts as a platform to combat pathogens, chronic diseases and viruses. Diatom derived bioactive compounds have been used in various therapeutic applications [32].

Antiviral compounds :General mode of action of antiviral compounds

In the prevention of life-threatening bacterial diseases, the use of microbial of synthetically produced antibiotics are being commonly used from many decades. The development of drugs to effectively combat viral diseases, however has proven to be much more difficult. However, the advanced microbial techniques such as the coupling of three-dimensional structure and replication cycles of viral molecules, are now making possible the development of highly specific and effective antiviral drugs.

In principle, a molecule can act as an anti-viral drug if it inhabits some stage of the virus replication cycle, without being too toxic to the body cells. Further, the possible mode of actions of anti-viral agents may include- active extracellular virus particles, prevent viral entry or attachment, prevent replication of the viral genome, prevent synthesis of specific viral proteins, prevent assembly of release of new infectious virions and act as a protease inhibitor.

For example, the new drug Rupintrivir (Pfizer) is an inhibitor of rhinovirus protease $3 \mathrm{C}$ which act as a protease inhibitor and protease action to cut a polyprotein into individual viral proteins [33]. In another study researchers have described the genotype and pathogenesis of an inhibitor resistant coronavirus. Further, they showed that the inhibitor-resistant virus is attenuated both in cell culture and in infected mice [34].

\section{Macroalgae-derived antiviral compounds}

Polysaccharides or glycans, are the most abundant form of carbohydrate materials in the nature which has gained significant applications in biomedical and pharmaceutical industries [35]. Algae-derived polysaccharides were successfully introduced as an antiviral agent [36]. They found significant inhibition of mumps and Influenza B virus. Later, red algae polysaccharide fractions were tested as a potent source of antiviral agents against Herpes Simplex Virus (HSV) and other viruses in the next two decades. Since then, numerous studies have been published for the antiviral potential of various algae-derived polysaccharides. Red macroalgae like Kappaphycus alvarezii, Hypnea musciformis (carra- geenophytes) (Figure 2) cell wall contains sulphated polysaccharides, has similar property like Porphydium as a potential antiviral drug [8,37-40].

Three extracts (Diethyl ether, acetone and ethanol) of ten marine macroalgae belonging to Chlorophyceae, Rhodophyceae and Phaeophyceae isolated from Red sea, for its antibacterial, antifungal and antiviral activities against different organisms including Newcastle Disease Virus (NDV)-(Paramyxoviridae) which is responsible for acute respiratory distress in chicken [41]. Selectively, as far as antiviral activity is concerned, the result of the ethanol extracts showed that seven of the ten tested algal extracts have strong activities against NDV. In another review article they have explained in detailed about various algal polysaccharides containing antiviral activities, including carrageenan, alginate, fucan, and laminaran [35] (Figure 1). Moreover, different mechanisms of action for these polysaccharides, such as inhibiting the binding of virus into the host cells or suppressing DNA replication and protein synthesis. The entire review gives insightful view about antiviral studies of algae derived polysaccharides, mechanism of action towards their development as natural antiviral agents (Table 1).

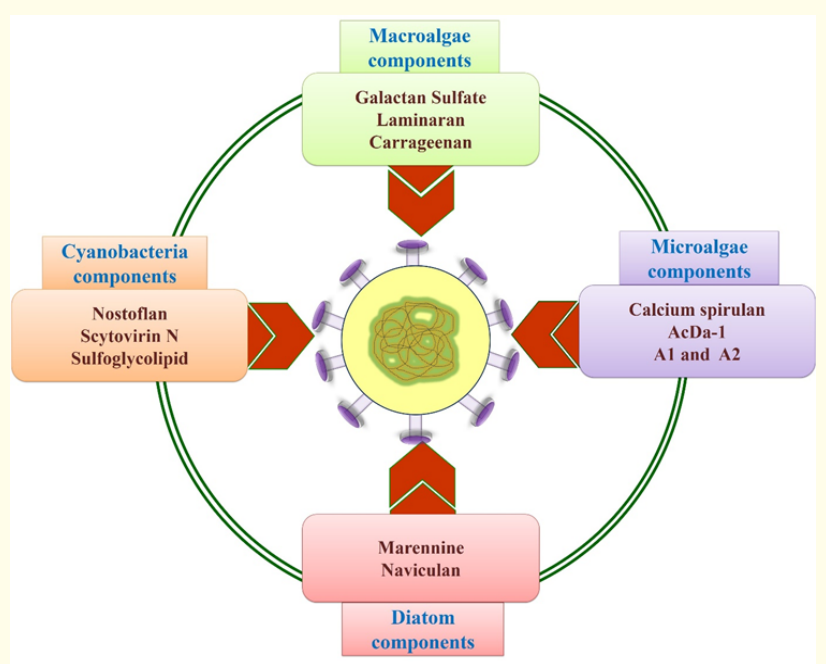

Figure 1: Schematic representation of biologically derived antiviral components against viruses.

Porphyridium cruentum, marine red algae have medicinally significant compounds in its exopolysaccharides [42]. During the growth when it reaches to the stationary phase it secretes exopolysaccharide (EPS) with sulphated polysaccharides which has the potential of antibacterial, antiviral and anti-inflammatory activity against human and animal viruses [43]. The antiviral activity of the red microalga Porphyridium sp. was also confirmed against herpes simplex virus [44]. 


\begin{tabular}{|c|c|c|c|c|}
\hline Compound & $\begin{array}{l}\text { Common } \\
\text { name }\end{array}$ & Organism & Virus & Reference \\
\hline Galactan Sulfate & Red alga & Agardhiella tenera & $\begin{array}{l}\text { HIV-1 and HIV-1 CPE and syncytia formation; } \\
\text { Other enveloped viruses (herpes viruses, } \\
\text { togaviruses, arenaviruses, etc.) }\end{array}$ & [45] \\
\hline Griffithsin & Red alga & Griffithsia sp. & HIV-1 glycoproteins (e.g., gpl20, gp41 and gpl60) & [46] \\
\hline Sea Algae extract & Red alga & Schizymenia pacifca & HIV RT; AMV RT; RMLV RT & [47] \\
\hline \multirow[t]{2}{*}{ Carrageenan } & Red alga & $\begin{array}{l}\text { Chondrus, Gigartina, Hypnea, and } \\
\text { Eucheuma }\end{array}$ & $\begin{array}{l}\text { Influenza virus, DENV, HSV-1, HSV-2, HPV, } \\
\text { HRV, HIV }\end{array}$ & [48] \\
\hline & Red alga & Porphiridium sp. & Herpes simplex virus. & [44] \\
\hline Galactan & Red algae & $\begin{array}{l}\text { Callophyllis variegate, Agardhiella } \\
\text { tenera, Schizymenia binderi, } \\
\text { Cryptonemia crenulata }\end{array}$ & HSV-1, HSV-2, HIV-1, HIV-2, DENV, HAV & [49] \\
\hline Fucoidan & Brown alga & Fucus vesiculosus & $\begin{array}{c}\text { HSV-1 and HSV-2; HCMV; VSV; Sinbis virus; HIV-1 } \\
\text { RT }\end{array}$ & {$[50]$} \\
\hline Alginate & Brown alga & $\begin{array}{c}\text { Laminaria hyperborea, Laminaria } \\
\text { digitata, Laminaria japonica, } \\
\text { Ascophyllum } \\
\text { nodosum, Macrocystis pyrifera }\end{array}$ & HIV, IAV, HBV & [51] \\
\hline Fucan & Brown alga & $\begin{array}{c}\text { Adenocytis utricularis, Undaria } \\
\text { pinnatifida, Stoechospermum } \\
\text { marginatum, } \\
\text { Cystoseira indica, Cladosiphon } \\
\text { okamuranus, Fucus } \\
\text { vesiculosus }\end{array}$ & HSV-1, HSV-2, HCMV, VSV, Sindbis virus, HIV-1 & [52] \\
\hline Laminaran & Brown alga & $\begin{array}{l}\text { Fucus vesiculosus, Saccharina } \\
\text { longicruris, Ascophyllum nodosum }\end{array}$ & Influenza A virus & [53] \\
\hline
\end{tabular}

Table 1: Antivirals derived from marine macroalgae.

\section{Microalgae-derived antiviral compounds}

Algae may produce antiviral compounds is a known fact [23]. However, there is yet to be an opportunity to hunt for many unknown bioactive compounds from these natural resources. A sulphated polysaccharide, calcium spirulan (Ca-SP) isolated from Spirulina platensis has been showed to possess antiviral activities (Figure 1). This study reveals that, a sulphated polysaccharide composed of different compounds which was found to be inhibit the several enveloped viruses such as, Herpes simplex type-1, Human cytomegalovirus, measles virus, mumps virus, influenza-A virus and HIV-1 [54,55].

The aqueous extracts of Porphyridium cruentum, Chorella autotrophica and Ellipsoidon sp. showed significant inhibition of the in vitro replication of haemorrhagic septicemia virus and African swine fever virus [56]. The production of retroviruses (murine leukemia virus- MuLV) were significantly inhibited by red microalgal polysaccharides and cell transformation by murine sarcoma virus (MuSV-124) in cell culture. Polysaccharides derived from red microalgae significantly inhibited the production of retroviruses (MuLV) and cell transformation by MuSV-124 in cell culture [57] (Table 2).

Other selective marine algae-derived antiviral compounds

Microalgae and Cyanobacteria are known to produce many antioxidant molecules including antimicrobial, anticancer and antiviral activities [41]. Hence, the usages of these organism have increased for research and development purposes. Similarly, compared to other higher plants microalgae and Cyanobacteria can be scaled up in minimum period with significant growth rate to produce antiviral compounds [60]. The sulphated polysaccharides of Cyanobac- 


\begin{tabular}{|l|c|c|c|c|}
\hline Compound & $\begin{array}{c}\text { Common } \\
\text { name }\end{array}$ & Organism & Virus & Reference \\
\hline A1 & Microalgae & Cochlodinium polykrikoides & Influenza virus A and B; RSV A and B; HSV-1 & {$[58]$} \\
\hline A2 & Microalgae & Cochlodinium polykrikoides & $\begin{array}{c}\text { Influenza virus A and B; RSV A and B; } \\
\text { parainfluenza type 2 }\end{array}$ & {$[58]$} \\
\hline AcDa-1 & & Dictyota menstrualis & $\begin{array}{c}\text { HIV-1 replication and RNA-dependent DNA } \\
\text { polymerase } \\
\text { activity of the viral RT }\end{array}$ & {$[59]$} \\
\hline $\begin{array}{l}\text { Calcium } \\
\text { spirulan }\end{array}$ & Microalgae & Spirulina platensis & $\begin{array}{c}\text { Herpes simplex virus type 1, human } \\
\text { cytomegalovirus, measles virus, mumps } \\
\text { virus, influenza A virus, and HIV-1 }\end{array}$ & {$[54-55]$} \\
\hline & Microalgae & $\begin{array}{c}\text { Chlorella autotrophica and } \\
\text { Ellipsoidon sp. }\end{array}$ & $\begin{array}{c}\text { Haemorrhagic septicemia virus and African } \\
\text { swine fever virus }\end{array}$ & {$[56]$} \\
\hline & Microalgae & Porphyridium sp. & MuSV-124, MuSV/MuLV & {$[57]$} \\
\hline & Microalgae & P. aerugineum & MuSV-124, MuSV/MuLV & {$[57]$} \\
\hline & Microalgae & Rhodella reticulata & MuSV-124, MuSV/MuLV & {$[57]$} \\
\hline
\end{tabular}

Table 2: Antivirals derived from marine microalgae.

teria, Spirulan has a potential antiviral activity against herpes simplex virus type 1 (HSV-1) and the human immunodeficiency virus type 1 (HIV-1) [61].

In one study, more than $80 \%$ inhibition of seasonal influenza A and B replication in Madin-Darby-Canine Kidney (MDCK) cells occurred from seven extracts derived from microalgae and Cyanobacteria in ethyl acetate solvent [62]. Two extracts from Leptolyngbya sp. (Cyanobacteria) and Chlorellaceae family (microalgae) inhibited influenza A and B replication and neuraminidase activity, from the oseltamivir, (OST, a neuraminidase inhibitor) sensitive and resistance strains and lineages. Thus, these organisms are important for bioprospecting in antiviral research. Similarly, an in vitro study has showed that, red and blue green algae has potential antiviral lectins which can combat against Hepatitis C viruses [63]. Spirulan and Caspirulan from significant antiviral cancer polysaccharides are from Spirulina sp. These compounds from the extracts of Cyanobacteria showed potent and broad-spectrum activity against HIV-1, HIV-2, H. influenza and a series of other enveloped viruses. At the same time components such as cynovirin-N and scytovirin, the carbohydrate binding proteins are being developed as potential virucidal drugs [64] (Table 3).

The extraction of polysaccharides marine microalgae viz. Naviculum from diatom Navicula directa, A1 and A2 from dinoflagellates, Cochlodinium polykrikoides showed antiviral activities against several enveloped viruses, such as HIV-1, HSV-1 or influenza virus type A (IFV-A) [65]. Diatoms has excellent antiviral properties with polyphenolic and antioxidant compounds e.g. diatoms, Haslea sp. [66]. An antiviral and antioxidant potential of marine microorganisms which can be useful to develop a natural "antiviral pharmacy" to combat against diverse viruses [67] (Figure 1).

Molecular tool development for targeted drugs (Synthetic biology and digital platform)

In current pandemic to fight against COVID-19 the molecular farming community is extensively active in establishing plantbased processes to produce diagnostic and therapeutic proteins. Currently, two EU consortia viz. H2020 projects Pharma-Factory and Newcotiana are focusing on molecular farming to establish plant-based platforms for the industrial applications to develop such proteins on high priority. At present, manufacturing of protein antigens and antibodies for diagnostic kits, therapeutic products, antiviral drugs, vaccines and scalable production systems is global urgency hence cooperation with such production companies for product formation and its commercialization is very crucial. Such opportunity creations or models will not only help in this present COVID-19 situation but also in future pandemics [70].

Recently, due to rapid applications of biotechnological or molecular tools in drug discovery and vaccine development, pharmaceutical companies are in a decent position in quality drugs production at industrial scales in stipulated time. Before the dawn of biotechnology era, drug discovery and development took many decades to produce effective medicines against different types of infectious diseases. Advancement in genomics, proteomics, 


\begin{tabular}{|c|c|c|c|c|}
\hline Compound & Common name & Organism & Virus & Reference \\
\hline $\begin{array}{l}\text { Calcium } \\
\text { spirulan }\end{array}$ & Cyanobacteria & $\begin{array}{l}\text { Arthrospira platensis (previously } \\
\text { called Spirulina platensis) }\end{array}$ & $\begin{array}{l}\text { HSV-1 replication; Measles replication; Mumps } \\
\text { replication; } \\
\text { Influenza replication; Polio replication; Coxsackie } \\
\text { replication; } \\
\text { HIV-1 replication; HCMV replication; Selectively } \\
\text { inhibition of penetration into host cells }\end{array}$ & {$[54]$} \\
\hline $\begin{array}{l}\text { Cyanovirin-N } \\
\text { Da-1 }\end{array}$ & Cyanobacteria & Nostoc ellipsosporum & $\begin{array}{c}\text { HIV-1 and HIV-2 and SIV fusion, replication and CPE } \\
\text { HIV-1 replication and RNA-dependent DNA } \\
\text { polymerase } \\
\text { activity of the viral RT }\end{array}$ & $\begin{array}{l}{[68]} \\
{[59]}\end{array}$ \\
\hline Spirulan & Cyanobacteria & Spirulina sp. & $\begin{array}{l}\text { HIV-1 and HIV-2 (inhibit reverse transcriptase) } \\
\text { HSV, influenza }\end{array}$ & {$[64]$} \\
\hline Nostoflan & Cyanobacteria & Nostoc flagilliforme & $\begin{array}{c}\text { HSV-1 (HF), HSV-2 (UW-268), HCMV(Towne) } \\
\text { Influenza (NWS), Adeno (type 2), Coxsackie } \\
\text { (Conn-5) }\end{array}$ & [64] \\
\hline Scytovirin N & Cyanobacteria & Scytonema varium & $\begin{array}{l}\text { HIV-1 (interacts with oligosaccharides conaining } \\
\text { a1-2, a1-2, a1-6 tetramannose units of } \\
\text { envelope glycoproteins, gp120, gp160, gp 41) }\end{array}$ & {$[64]$} \\
\hline Sulfoglycolipid & Cyanobacteria & Scytonema sp. & $\begin{array}{l}\text { HIV-1 (inhibit reverse transcriptase and DNA } \\
\text { polymerases) }\end{array}$ & {$[64]$} \\
\hline Marennine & Diatoms & Haslea sp. & HSV-1 & {$[66]$} \\
\hline Naviculan & Diatom & Navicula directa & $\begin{array}{l}\text { HSV-1 and HSV-2 adhesion, penetration and } \\
\text { replication }\end{array}$ & [69] \\
\hline
\end{tabular}

Table 3: Antivirals derived from other marine algae.

Artificial Intelligence (AI) based modelling and prediction helped further to expedite drug development and vaccine production. In vitro studies of sulphated Polysaccharide extracted from the seaweed Saccharina japonica effectively bind to the S-protein of SARS-CoV-2 with less toxicity when compared to Remdesvir medicine [71]. Recently researchers from Western University (Canada) and Suncor have jointly proposed to use microalgae as diagnostic kits for COVID 19. In another study by University of Pittsburgh School of Pharmacy planned to express Q-griffithsin molecule from Griffithsia in tobacco plant and use as nasal drops. Further, it has compared the over expression of Griffithsin in various expression systems [72]. In E. coli (fermenter based) yield was $819 \mathrm{mg} / \mathrm{L}$ and after purification $542 \mathrm{mg} / \mathrm{L}$; tobacco leaves yield $1 \mathrm{~g} / \mathrm{kg}$ and after purification $300 \mathrm{mg} / \mathrm{kg}$; in rice seeds yield was $301 \mathrm{mg} / \mathrm{kg}$ dry seed and after purification $223 \mathrm{mg} / \mathrm{kg}$. Countries like Israel and Italy working on microalgae as edible drugs [73]. Docking and in silico toxicity assessment of 3 molecules of phycocyanobilin, phycoerythrobilin and folic acid from Arthrospira showed anti-SARS-CoV-2 activity [74].

Another recent studies state that, Guangxi University and Huazhong Agriculture university researchers used a 3D homology model of the sequence to screen against more than 32,000 potential antiviral phytochemicals and traditional Chinese medicinal compounds. This effort led to 9 specific plant molecules that may be used to develop drugs against COVID 19 [75]. Indonesian researchers used molecular docking to search for potential inhibitors of COVID-19 main protease (Mpro), a potential drug target. They searched a bioactive compound in which luteolin-7-glucoside, demethoxycurcumin, apigenin-7-glucoside, oleuropein, curcumin, catechin, and epicatechin-gallate have the best potential to act as COVID-19 Mpro inhibitors. Further studies have suggested for its confirmations and potential medicinal usages [76]. University of Maragheh also conducted molecular docking study which led to nine neutral and low risk drugs that have inhibitory activities against COVID-19 protease [77]. These advanced synthetic biology and digital platform approaches may help to produce targeted medicines at industrial scales in very less time to combat against infectious viral and other diseases.

\section{Conclusion}

The present COVID-19 pandemic has highlighted the importance and priority of discovery compounds from marine natural 


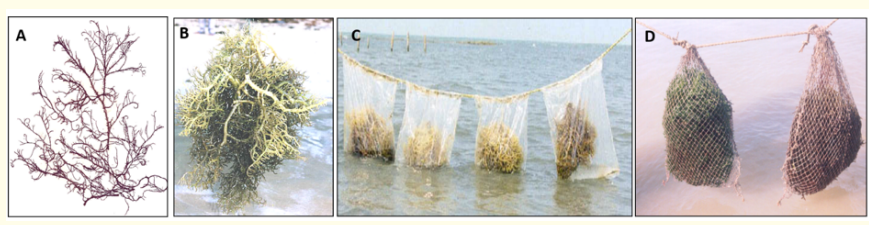

Figure 2: Macroalgae A. Hypnea musciformis. B. Kappaphycus alvarezii, Macroalgae cultivation methods. C. In plastic bags. D. in Nylon bags [38,39].

resources for the prevention and treatment of severe and acute viral infections. To the best of our knowledge, Macroalgae, microalgae, Cyanobacteria and diatoms are excellent source of antiviral activity. Several cyclic or linear peptides and depsipeptides isolated from Cyanobacteria are protease inhibitors, which is considered as significant antiviral candidate. Numerous in vitro or in vivo studies has shown the potential of algae against wide range of viruses. The use of natural products in the manufacturing of drugs is an ancient and well-established practice. In our opinion, the pharmaceutical potential of marine algae deserves more scientific attention, interdisciplinary research along with its diverse habitat explorations to find novel compounds to control viral diseases in humans and probably in recent pandemic, COVID-19.

\section{Conflicts of Interest}

The authors declare that there are no conflicts of interest.

\section{Acknowledgments}

We thank Reliance Industries Limited and fellow colleagues for their advice and help in writing and reviewing the manuscript.

\section{Bibliography}

1. World Health Organization. "The world health report 2007 - A safer future: global public health security in the $21^{\text {st }}$ century". Geneva: World Health Organization (2008).

2. C A Devaux. "Emerging and re-emerging viruses: A global challenge illustrated by Chikungunya virus outbreaks". World Journal of Virology 1.1 (2012): 11-22.

3. A E Gorbalenya., et al. "The species severe acute respiratory syndrome-related coronavirus: classifying 2019-nCoV and naming it SARS-CoV-2". Nature Microbiology 5 (2020): 536-544.
4. K Kupferschmidt and J Cohen. "Will novel virus go pandemic or be contained?" Science 367.6478 (2020): 610-611.

5. N Mohammadi and N Shaghaghi. "Inhibitory Effect of Eight Secondary Metabolites from Conventional Medicinal Plants on COVID_19 Virus Protease by Molecular Docking Analysis". Preperint (2020).

6. M Skulberg. "Bioactive chemicals in microalgae". In: Richmond, A. (Ed.), Handbook of microalgal culture: biotechnology and applied phycology. Blackwell Science Ltd., Oxford (2004): 485512.

7. S Singh., et al. "Bioactive compounds from cyanobacteria and microalgae: an overview". Critical Reviews in Biotechnology 25 (2005): 73-95.

8. R Pratt and J Fong. "Studies on Chlorella vulgaris. Further evidence that chlorella cells form a growth inhibiting substance". American Journal of Botany 27 (1940): 431-436.

9. R Sathasivam., et al. "Microalgae metabolites: A rich source for food and medicine". Saudi Journal of Biological Sciences 26 (2019): 709-722.

10. A M S Mayer., et al. "Marine pharmacology in 1998: Marine compounds with antibacterial, anticoagulant, antifungal, antiinflammatory, anthelmintic, antiplatelet, antiprotozoal, and antiviral activities; with actions on the cardiovascular, endocrine, immune, and nervous systems; and other miscellaneous mechanisms of action". Pharmacologist 42 (2000): 62-69.

11. D Rangel-Huerta., et al. "Systematic review of the efficacy of bioactive compounds in cardiovascular disease: phenolic compounds". Nutrients 7 (2015): 5177-5216.

12. D J Newman and G M Cragg. "Natural products as sources of new drugs from 1981 to 2014". Journal of Natural Products 79 (2016): 629-661.

13. I Belghit., et al. "In-depth metabolic profiling of marine macroalgae confirms strong biochemical differences between brown, red and green algae". Algal Research 26 (2017): 240249.

14. C S Kumar., et al. "Seaweeds as a Source of Nutritionally Beneficial Compounds-A Review". Journal of Food Science and Technology 45 (2008): 1-13. 
15. AJ Smit. "Medicinal and pharmaceutical uses of seaweed natural products: a review". Journal of Applied Phycology 16 (2004): 245-262.

16. M Barbosa., et al. "Bioactive compounds from macroalgae in the new millennium: implications for neurodegenerative diseases". Marine Drugs 12 (2014): 4935-4972.

17. C M Ireland., et al. "Biomedical potential of marine natural products". In Attaway DH, ZaborskyOR (eds), Marine Biotechnology, Pharmaceutical and Bioactive Natural Products, Plenum Press, NY 1 (1993): 1-43.

18. A Kelecom. "Secondary metabolites from marine microorganisms". Anais da Academia Brasileira de Ciências 74 (2002): 151170.

19. A Pal., et al. "Bioactive Compounds and Properties of SeaweedsA Review". Open Access Library Journal 1 (2014): e752.

20. T M Mata., et al. "Microalgae for biodiesel production and other applications: A review". Renewable and Sustainable Energy Reviews 14 (2010): 217-232.

21. P Spolaore., et al. "Commercial applications of microalgae'. Journal of Bioscience and Bioengineering 101 (2006): 87-96.

22. S Santoyo., et al. "Antiviral compounds obtained from microalgae commonly used as carotenoid sources". Journal of Applied Phycology 24 (2012): 731-741

23. E B Damonte., et al. "Sulfated seaweed polysaccharides as antiviral agents". Current Medicinal Chemistry 11 (2004): 23992419.

24. A M S Mayer., et al. "Marine pharmacology in 2005-2006: Marine compounds with antihelmintic, antibacterial, anticoagulant, antidiabetic, antifungal, anti-inflammatory, antimalarial, antiplatelet, antiprotozoal, antituberculosis, and antiviral activities; affecting the cardiovascular, immune and nervous systems and other miscellaneous mechanisms of action". Biochimica et Biophysica Acta 1790 (2009): 283-308.

25. K Gademann and C Portmann. "Secondary metabolites from cyanobacteria: complex structure and powerful bioactivities". Current Organic Chemistry 12 (2008): 326-341.

26. V Ordog., et al. "Screening microalgae for some potentially useful agricultural and pharmaceutical secondary metabolites".
Journal of Applied Phycology 16 (2004): 309-314.

27. L T Tan. "Bioactive natural products from marine cyanobacteria for drug discovery". Phytochemistry 68 (2007): 954-979.

28. Y Chisti. "Biodiesel from microalgae". Biotechnology Advances 25 (2007): 294-306.

29. N V Wase and P C Wright. "Systems biology of cyanobacterial secondary metabolite production and its role in drug discovery". Expert Opinion on Drug Discovery 3 (2008): 903-929.

30. S Vijayakumar and M Menakha. "Pharmaceutical applications of cyanobacteria: A review". Journal of Acute Medicine 5 (2015): $15 \mathrm{e} 23$.

31. P Kuppusamy., et al. "Potential pharmaceutical and biomedical applications of Diatoms microalgae- An overview". IJMS 46.4 (2017): 663-667.

32. F Folmer., et al. "Photosynthetic marine organisms as a source of anticancer compounds". Phytochemistry Review 9 (2010): 557-579.

33. S L Binford., et al. "Conservation of Amino Acids in Human Rhinovirus 3C Protease Correlates with Broad-Spectrum Antiviral Activity of Rupintrivir, a Novel Human Rhinovirus 3C Protease Inhibitor". Antimicrobial Agents and Chemotherapy 49.2 (2005): 619-626.

34. X Deng., et al. "Coronaviruses Resistant to a 3C-Like Protease Inhibitor Are Attenuated for Replication and Pathogenesis, Revealing a Low Genetic Barrier but High Fitness Cost of Resistance". Journal of Virology 88.20 (2014): 11886-11898.

35. A Ahmadi., et al. "Antiviral Potential of Algae Polysaccharides Isolated from Marine Sources: A Review". BioMed Research International 2015 (2015): 10.

36. P Gerber., et al. "Protective effect of seaweed extracts for chicken embryos infected with influenza B or mumps virus”. Experimental Biology and Medicine 99.3 (1958): 590-593.

37. D W Ehresmann., et al. "Antiviral substances from California marine algae". Journal of Phycology 13.1 (1977): 37-40.

38. C R K Reddy., et al. "In vitro somatic embryogenesis and regeneration of somatic embryos from pigmented callus of Kappaphycus alvarezii (Doty) Doty (Rhodophyta, Gigartinales)". Journal of Phycology 39 (2003): 610-616. 
39. C R K Reddy., et al. "An Improved Process for Cultivation of Algae". US Patent No. 6858430 B1, (2005).

40. M S Gaikwad., et al. "On occurrence of the genus Porphyridium nageli: New to India". Journal of Algal Biomass Utilization 1.1 (2009): 102-106.

41. I B M Ibraheem., et al. "Evaluation of antibacterial, antifungal and antiviral activities of ten marine macroalgae from Red Sea, Egypt". African Journal of Biotechnology 11.33 (2012): 83328340.

42. M Gaikwad., et al. "Marine red alga Porphyridium sp. as a source of sulfated polysaccharides (SPs) for combating against COVID-19". (2020).

43. C A Pujol., et al. "Novel dl-galactan hybrids from the red seaweed Gymnogongrus torulosus are potent inhibitors of herpes simplex virus and dengue virus". Antiviral Chemistry and Chemotherapy 13 (2002): 83-89.

44. H Mahmoud., et al. "Activity of Porphyridium sp. polysaccharide against herpes simplex viruses in vitro and in vivo". Journal of Biochemical and Biophysical Methods 50 (2002): 189-200.

45. M Witvrouw., et al. "Antiviral activity of a sulfated polysaccharide extracted from the red seaweed Aghardhiella tenera against human immunodeficiency virus and other enveloped viruses". Antiviral Chemistry and Chemotherapy 5 (1994): 297303.

46. T Mori., et al. "Isolation and characterization of griffithsin, a novel HIV-inactivating protein, from the red alga Griffithsia sp". Journal of Biological Chemistry 280 (2005): 9345-9353.

47. H Nakashima., et al. "Purification and characterization of an avian myeloblastosis and human immunodeficiency virus reverse transcriptase inhibitor, sulfated polysaccharides extracted from sea algae". Antiviral Chemistry and Chemotherapy 31 (1987a): 1524-1528.

48. M Lahaye. "Developments on gelling algal galactans, their structure and physico-chemistry". Journal of Applied Phycology 13.2 (2001): 173-184.

49. J M Estevez., et al. "DL-Galactan hybrids and agarans from gametophytes of the red seaweed Gymnogongrus torulosus". Carbohydrate Research 331.1 (2001): 27-41.
50. A Beress., et al. "A new procedure for the isolation of anti-HIV compounds (polysaccharides and polyphenols) from the marine alga Fucus vesiculosus". Journal of Natural Products 56 (1993): 478-488.

51. X Xianliang., et al. "Study on the mechanism of inhibitory action of 911 on replication of HIV-1 in vitro". Chinese Journal of Marine Drugs 19.4 (2000): 15-22.

52. K IP J Hidari., et al. "Structure and anti-dengue virus activity of sulfated polysaccharide from a marine alga". Biochemical and Biophysical Research Communications 376.1 (2008): 91-95.

53. M Kim., et al. "In vitro inhibition of influenza A virus infection by marine microalga-derived sulfated polysaccharide p-KG03". Antiviral Research 93.2 (2012): 253-259.

54. T Hayashi., et al. "Calcium spirulan an inhibitor of enveloped virus replication, from a blue-green alga Spirulina platensis". Journal of Natural Products 59 (1996): 83-87.

55. J B Lee., et al. "Effects of structural modification of calcium spirulan, a sulfated polysaccharide from Spirulina platensis, on antiviral activity". Chemical and Pharmaceutical Bulletin 49 (2001): 108-110.

56. J Fabregas., et al. "In vitro inhibition of the replication of haemorrhagic septicemia virus (VHSV) and African swine fever virus (ASFV) by extracts from marine microalgae". Antiviral Research 44 (1999): 67-73.

57. M M Talyshinsky., et al. "Anti-viral activity of red microalgal polysaccharides against Retroviruses". Cancer Cell International 2 (2002): 8.

58. M Hasui., et al. "In vitro antiviral activities of sulfated polysaccharides from a marine microalga (Cochlodinium polykrikoides) against human immunodeficiency virus and other enveloped viruses". International Journal of Biological Macromolecules 17 (1995): 293-297.

59. H S Pereira., et al. "Antiviral activity of diterpenes isolated from the Brazilian marine alga Dictyota menstrualis against human immunodeficiency virus type 1 (HIV-1)". Antiviral Research 64 (2004): 69-76.

60. Skulberg. "Microalgae as a source of bioactive molecules - Experience from cyanophyte research". JAPH 12 (2000): 341-348. 
61. S Rechter., et al. "Antiviral activity of Arthrospira-derived spirulan-like substances". Antiviral Research 72 (2007): 197-206.

62. T Silva., et al. "Inhibitory effect of microalgae and cyanobacteria extracts on influenza virus replication and neuraminidase activity". Peer Journal 6 (2018): e5716.

63. Y Takebe., et al. "Antiviral Lectins from Red and Blue-Green Algae Show Potent In vitro and In vivo Activity against Hepatitis C. Virus". Plos One 8 (2013): 5.

64. R K Singh., et al. "Cyanobacteria: an emerging source for drug discovery". The Journal of Antibiotics 64 (2011): 401-412.

65. L X Zheng., et al. "Current trends in marine algae polysaccharides: The digestive tract, microbial catabolism, and prebiotic potential". International Journal of Biological Macromolecules 151 (2020): 344-354.

66. R Gastineau., et al. "Haslea karadagensis (Bacillariophyta): A second blue diatom, recorded from the Black Sea and producing a novel blue pigment". European Journal of Phycology 47 (2012): 469-479.

67. C Sansone., et al. "Marine Algal Antioxidants as Potential Vectors for Controlling Viral Diseases". Antioxidants 9 (2020): 392.

68. M R Boyd., et al. "Discovery of cyanovirin-N, a novel HIV-inactivating protein from Nostoc ellipsosporum that targets viral gp120". Int. Conf. AIDS 11 (2016): 71.

69. J B Lee., et al. "Antiviral sulfated polysaccharide from Navicula directa, a diatom collected from Deep-sea water in Toyama Bay". Biological and Pharmaceutical Bulletin 29 (2016): 21352139.

70. T Capell., et al. "Potential Applications of Plant Biotechnology against SARS-Cov-2". Trends in Plant Science 25 (2020): 7.

71. P S Kwon., et al. "Sulfated polysaccharides effectively inhibit SARS-CoV-2 in vitro". Cell Discovery 6.1 (2020): 1-4.

72. S Lusvarghi and C A Bewley. "Griffithsin: an antiviral lectin with outstanding therapeutic potential”. Viruses 8.10 (2016): 296.

73. B Gunasekaran and KM Gothandam. "A review on edible vaccines and their prospects". Brazilian Journal of Medical and Biological Research 53.2 (2020): e8749.
74. L Petit., et al. "Docking and in silico toxicity assessment of Arthrospira compounds as potential antiviral agents against SARS-CoV-2". (2020).

75. M T U l Qamar., et al. "Structural Basis of SARS-CoV-2 3CLpro and Anti-COVID-19 Drug Discovery from Medicinal Plants". Journal of Pharmaceutical Analysis (2020).

76. S Khaerunnisa., et al. "Potential inhibitor of COVID-19 main protease (Mpro) from several medicinal plant compounds by Molecular Docking". Study (2020).

77. N Shaghaghi. "Molecular Docking study of COVID-19 protease with low risk Terpenoides compounds of plants". ChemRxiv (2020).

\section{Assets from publication with us}

- Prompt Acknowledgement after receiving the article

- Thorough Double blinded peer review

- Rapid Publication

- Issue of Publication Certificate

- High visibility of your Published work

Website: www.actascientific.com/

Submit Article: www.actascientific.com/submission.php Email us: editor@actascientific.com

Contact us: +919182824667 